\title{
ELECTROPHYSIOLOGICAL EFFECTS OF DYNORPHIN PEPTIDES ON HIPPOCAMPAL PYRAMIDAL CELLS IN RAT *
}

\author{
HYLAN C. MOISES ** and J. MICHAEL WALKER *** \\ Department of Physiology and Mental Health Research Institute, University of Michigan, Ann Arbor, Michigan 48109, U.S.A.
}

Received 19 June 1984, revised MS received 2 October 1984, accepted 9 October 1984

H.C. MOISES and J.M. WALKER, Electrophysiological effects of dynorphin peptides on hippocampal pyramidal cells in rat, European J. Pharmacol. 108 (1985) 85-98.

Single-unit extracellular recording was carried out in rats to characterize the effects of dynorphin and several structurally related peptides on hippocampal pyramidal cell activity. Dynorphin, applied electrophoretically or by pneumatic pressure, produced a dose-dependent depression of both spontaneous and glutamate-evoked discharge in a majority (63\%) of $\mathrm{CA}_{1}$ and $\mathrm{CA}_{3}$ cells tested. In addition, a small number of cells in both cellular fields responded to the peptide with a prolonged elevation in firing. The inhibitory effects of dynorphin were not blocked by naloxone. Moreover, administration of des-tyrosine-dynorphin depressed the firing of pyramidal cells in a manner similar to that of the parent compound. Ethylketocyclazocine produced a mixed pattern of excitatory and inhibitory effects, whereas naloxone-sensitive elevations in firing were most often observed with the application of dynorphin-(1-8). Application of $\left[\mathrm{Leu}^{5}\right]$ enkephalin produced only facilitations in pyramidal cell firing. The possibility is raised that biologically significant non-opiate actions, in addition to potent opiate-mediated effects, may occur upon release of pro-dynorphin peptides in the hippocampus.

Non-opiate effects $\kappa$ Opioid

\section{Introduction}

In vitro pharmacological studies strongly suggest that dynorphin interacts with $\kappa$ opioid binding sites (Chavkin et al., 1982, Corbett et al., 1982; James et al., 1984). Thus, dynorphin resembles ethylketocyclazocine and other putative opiate agonists in a number of in vitro bioassays utilizing smooth muscle (Huidobro-Toro et al., 1981;

* This work was supported by NIDA grants DA-03365. DA-04183 (H.A.), and an award from The Chicago Community Trust/Searle Scholars Program to H. Moises. J.M. Walker is a recipient of NIDA Post-doctoral Fellowship DA-04183.

** To whom all correspondence should be addressed at University of Michigan.

*** Present address: Walter S. Hunter Laboratory of Psychology, Department of Psychology, Brown University, Providence, RI 02912, U.S.A.
Chavkin et al., 1982; Yoshimura et al., 1982). Moreover, the binding of $\left[{ }^{3} \mathrm{H}\right]$ dynorphin to brain neural membranes is not readily displaced by opiates such as dihydromorphine or $\left[\mathrm{D}-\mathrm{Ala}^{2}, \mathrm{D}\right.$ $\mathrm{leu}^{5}$ ]enkephalin, but is easily displaced by $\kappa$ opioid agonists (Young et al., 1983). Paradoxically, dynorphin is equipotent in displacing tritiated $\mu$ and $\kappa$ compounds from rat neural membranes (Young et al., 1983). Nevertheless, it is quite clear from the ability of naloxone to completely block all of these effects that dynorphin has definite opiate actions that resemble those of the opiates.

The in vivo pharmacology of dynorphin largely encompasses the predicted set of $\kappa$ opioid effects, but is suggestive of a wide range of non-opiate effects as well. Thus, a number of the effects of dynorphin observed in rats and mice are completely unaffected by extremely high doses of naloxone. Most prominent among these are its 
effect on motor activity and grooming behavior (Herman et al., 1980; Walker et al., 1981), changes in the electroencephalogram (Walker et al., 1982a), and its depressant effects on hippocampal unit firing (Walker et al., 1982a). The non-opioid nature of these effects is further documented by the finding that at least this subset of dynorphin effects is equally well produced by des-Tyr-dynorphin, a fragment devoid of potency in displacing $\mu, \delta$ or $\kappa$ opiates from their binding sites in the central nervous system (CNS) (Walker et al., 1982a). Other effects of dynorphin, such as the inhibition of morphine analgesia (Walker et al., $1982 \mathrm{~b}$ ), the production of spinally mediated inhibition of thermal pain (Przewlocki et al., 1983), the elicitation of grooming (Aloyo et al., 1982), and motor paralysis (Faden and Jacobs, 1984), are also mimicked by des-Tyr-dynorphin. Taken together, these findings suggest that the in vivo pharmacology of dynorphin has two components, one which is opiate in nature and mediated through the familiar opiate receptor mechanisms and another which is non-opiate and mediated through an unknown mechanism.

In the present study, a further evaluation was carried out of the effects of dynorphin on single neurons in the rat CNS. The experiments were conducted in hippocampus because dynorphin is present there in significant amounts (Khachaturian et al., 1982; McGinty et al., 1983), and because much insight has recently been gained into the effects of opioid peptides in this brain structure (Zieglgänsberger et al., 1979; Dunwiddie et al., 1980; Dingledine, 1981; Siggins and Zieglgänsberger, 1981). The primary aim was to characterize relationships among several related compounds with opiate activity: the putative $\kappa$ opiate agonist ethylketocyclazocine, dynorphin, an amino-terminal fragment of dynorphin believed to be the major dynorphin-like peptide released in the CNS (dynorphin-(1-8)) (Weber et al., 1982) and $\left[\mathrm{Leu}^{5}\right]$ enkephalin.

\section{Materials and methods}

Thirty-eight male Sprague-Dawley rats (Charles River), weighing 225-320 g, were used in this study.
In the initial experiments $(n=16)$, animals were anesthetized with chloral hydrate, $400 \mathrm{mg} / \mathrm{kg}$ i.p.. with additional injections of approximately 80 $\mathrm{mg} / \mathrm{kg}$ being given as needed. In the remaining experiments $(n=22)$, anesthesia was induced with halothane $(2.5 \%$ in air), the animal intubated and then maintained at $0.5-0.75 \%$ halothane for the rest of the experiment. After the animal was fixed in a stereotaxic apparatus, a craniotomy was performed over the frontoparietal cortex. extending from 2.5 to $4.0 \mathrm{~mm}$ posterior to bregma and 1.0 to $4.0 \mathrm{~mm}$ lateral from the midline. The dura was excised and the exposed cortical surface covered with $2 \%$ agar in balanced salt solution to prevent drying. Body temperature was maintained constant at $37^{\circ} \mathrm{C}$ by means of a servo-feedback circuit.

Five-barreled glass micropipettes ( $3-6 \mu \mathrm{m}$ diameter tips), constructed according to the procedures of Palmer et al. (1980), were used to record extracellularly from single hippocampal pyramidal cells and to apply drugs in the immediate vicinity of the neuron being recorded. The center barrel, filled with $4 \mathrm{M} \mathrm{NaCl}$ or a solution of $2 \mathrm{M} \mathrm{NaCl}$ saturated with fast green dye, was used for recording. Three side barrels were backfilled with various combinations of the following solutions: dynorphin (dynorphin-(1-17)) $4 \mathrm{mM}$; dynorphin-(1-8) $8 \mathrm{mM}$ (Peninsula Laboratories, Inc.); des-Tyr-dynorphin (dynorphin-(2-17)) 5-10 mM; [Leu ${ }^{5}$ ]enkephalin $25 \mathrm{mM}$ (Peninsula Laboratories, Inc.): ethylketocyclazocine $10 \mathrm{mM}, \mathrm{pH} 4$ (SterlingWinthrop); naloxone hydrochloride $50 \mathrm{mM}, \mathrm{pH} 4$ (Endo Laboratories); L-glutamate $250 \mathrm{mM}, \mathrm{pH} 8$ (Sigma), bicuculline $50 \mathrm{mM}, \mathrm{pH} 5$ (Sigma) and $\mathrm{MgCl}_{2} 100 \mathrm{mM}$, pH 6 (Sigma). Dynorphin and des-Tyr-dynorphin were synthesized by solid phase methods by Dr. D.H. Coy (Tulane University) and provided generously as a gift. All peptides were dissolved in $0.9 \% \mathrm{NaCl}(\mathrm{pH} \mathrm{6.5-7.0)}$ and ejected from the barrels either by application of pneumatic pressure (1-25 psi range, 5-15 s) or with cationic current by electroosmosis. In some instances, peptides were ejected from the same barrel using both methods. The remaining drugs were ejected microiontophoretically as cations, except for glutamate which was ejected as an anion, or retained in the barrels by application of $15 \mathrm{nA}$ 
holding currents of opposite polarity. Automatic current balancing was maintained through a fourth peripheral barrel containing $3 \mathrm{M} \mathrm{NaCl}$. Positive and negative currents were independently passed through this barrel to check for possible current artifacts. In both the pressure ejection and electrophoretic experiments, all responses to given doses of drugs had to share reproducibility and reversibility over several trials to be considered valid. Control ejections were used to test for $\mathrm{pH}$ effects of the drug solutions as well as for pressure ejection artifacts. In some experiments, glutamate was intentionally leaked from one peripheral barrel in order to increase the firing rate of slowing discharging units and to activate normally quiescent cells.

Extracellular action potentials were recorded from single hippocampal pyramidal neurons within the $\mathrm{CA}_{1}$ and $\mathrm{CA}_{3}$ cellular fields. To facilitate accurate localization of the recording pipette to either $\mathrm{CA}_{1}$ or $\mathrm{CA}_{3}$, field potential analysis was often performed with the aid of a bipolar stimulating electrode placed ipsilaterally in the dentate hilus. Both stimulation and recording locations were within the same coronal plane, with the stimulating electrode maintained at a position of $1.2 \mathrm{~mm}$ medial to the midline. Hippocampal neurons were most frequently encountered in the region where the maximum amplitude of the evoked population spike response was observed.
Action potentials of pyramidal neurons, identified by their depth from the cortical surface and typical bursting pattern, were monitored on an oscilloscope, separated from background activity and converted to uniform voltage pulses by a window discriminator. These pulses were integrated over intervals of 1 or $2 \mathrm{~s}$ by an electronic ratemeter and the average firing rate of the cells displayed on a strip chart recorder to monitor drug effects. Constancy of spike amplitude was also monitored throughout the course of each experiment to control for local anesthetic effects of the drugs being tested. Upon termination of an experiment, the position of the recording site was marked by passing an anionic current of 20-30 $\mu \mathrm{A}$ for $10 \mathrm{~min}$ through the recording barrel, thus depositing a spot of fast green dye at the electrode tip. The location of the recording site, with respect to the $\mathrm{CA}_{1}$ and $\mathrm{CA}_{3}$ hippocampal fields, was then verified histologically in $50 \mu \mathrm{m}$ frozen sections stained with cresyl violet and neutral red.

\section{Results}

The effects of dynorphin and several structurally related opioid peptides were examined on 104 hippocampal pyramidal neurons. Thirty-nine of these cells were recorded in rats $(n=16)$ anesthetized with chloral hydrate and the remainder re-

TABLE 1

Effects of dynorphin and structurally related peptides on hippocampal pyramidal cell activity.

\begin{tabular}{|c|c|c|c|c|c|}
\hline \multirow[t]{2}{*}{ Test substance } & \multicolumn{5}{|c|}{ Response to peptide application } \\
\hline & Total cells & Excitation & Inhibition & Biphasic & No response \\
\hline \multicolumn{6}{|l|}{ CA, pvramidal cells } \\
\hline Dynorphin & 37 & 4 & 24 & 4 & 5 \\
\hline Des-Tyr-dynorphin & 8 & 0 & 4 & 0 & 4 \\
\hline Dynorphin-(1-8) & 7 & 3 & 0 & 0 & 4 \\
\hline$\left[\mathrm{Leu}^{5}\right]$ enkephalin & 8 & 5 & 0 & 1 & 2 \\
\hline Ethylketocyclazocine & 9 & 2 & 3 & 2 & 2 \\
\hline \multicolumn{6}{|l|}{$C A_{3}$ pyramidal cells } \\
\hline Dynorphin & 44 & 6 & 27 & 4 & 7 \\
\hline Des-Tyr-dynorphin & 11 & 1 & 7 & 0 & 3 \\
\hline Dynorphin- $(1-8)$ & 12 & 5 & 3 & 0 & 4 \\
\hline$\left[\mathrm{Leu}^{5}\right.$ ]enkephalin & 8 & 7 & 0 & 0 & 1 \\
\hline Ethylketocyclazocine & 10 & 2 & 3 & 3 & 2 \\
\hline
\end{tabular}


corded in halothane-anesthetized animals $(n=22)$. Individual $\mathrm{CA}_{1}$ and $\mathrm{CA}_{3}$ pyramidal cells responded qualitatively in the same direction to a particular opioid peptide under both anesthetic conditions. Furthermore, no clear relationships could be observed between the responsiveness of neurons to the opioids and their location within the $\mathrm{CA}_{1}$ and $\mathrm{CA}_{3}$ cellular fields. Results obtained at different electrode positions within the hippocampus and under the differing conditions of anesthesia have, therefore, been grouped together. Table 1 summarizes the effects produced by dy-

A
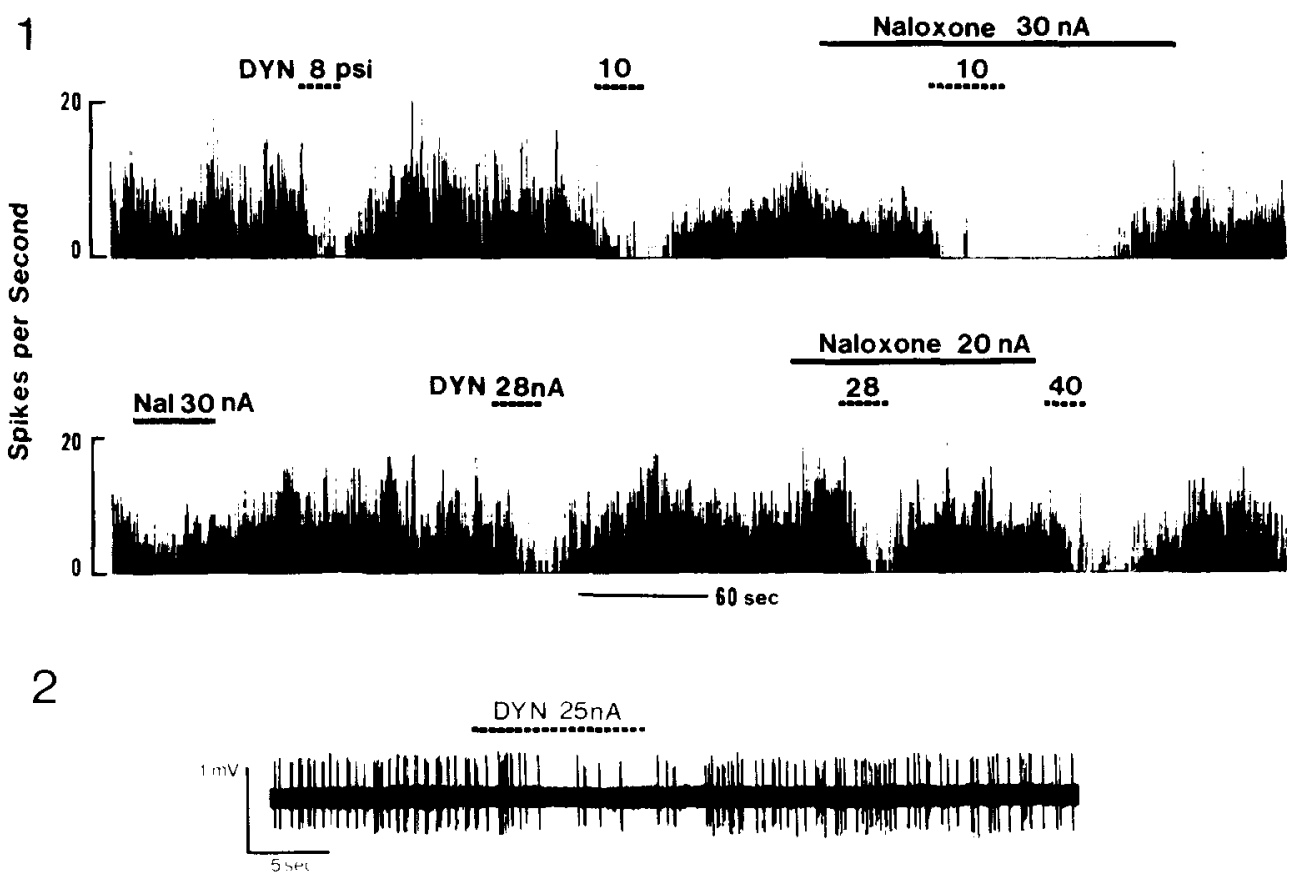

B

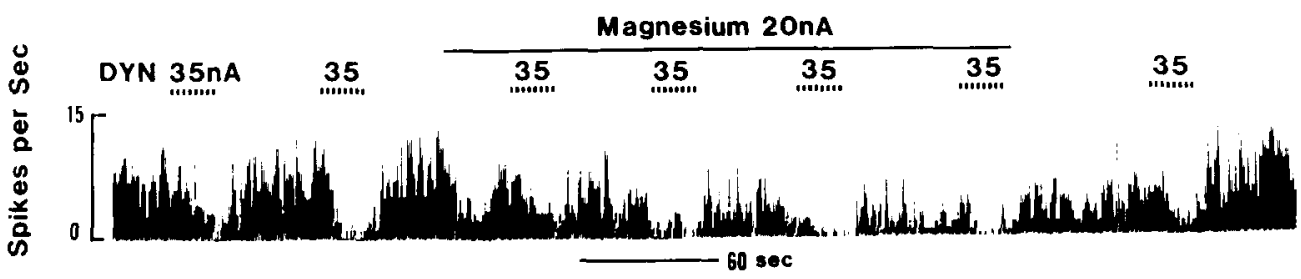

Fig. 1. $\left(A_{1}\right)$ Continuous ratemeter record shows dose-dependent inhibitory effect of dynorphin (DYN) on the spontaneous activity of a $C A_{1}$ pyramidal cell. Note that application of DYN (dashed line) by pneumatic (upper record) and electrophoretic ejection (lower record) produced similar inhibitory effects. Iontophoresis of naloxone (solid line) failed to block or reverse inhibitions produced by DYN. Note also that administration of naloxone at high dose levels ( $30 \mathrm{nA}$, lower record) produced a direct slowing of pyramidal cell activity. $\left(\mathrm{A}_{2}\right)$ Oscilloscope record shows the effects of electrophoretic application of DYN on the discharge frequency and spike amplitude of the pyramidal cell shown in (1). Application of DYN (dashed line) $25 \mathrm{nA}$ produced a clear reduction in the firing rate, accompanied by only a slight decrease in the size of the extracellularly recorded action potentials. (B) Results from an experiment on another $\mathrm{CA}_{1}$ pyramidal cell show little effect of magnesium iontophoresis (thin line) $20 \mathrm{nA}$ on inhibitions in firing produced by electrophoretic applications of DYN (dashed line) $35 \mathrm{nA}$. In this and all subsequent figures, bars above ratemeter records indicate time and duration of drug application. Numbers above bars correspond to the cjection dose level, with electrophoretic or pneumatic delivery being indicated in nanoamperes $(\mathrm{nA})$ or pounds per square inch (psi), respectively, at initial application of a particular agent. 
norphin, dynorphin-like peptides, [Leu ${ }^{5}$ enkephalin and ethylketocyclazocine in the 104 hippocampal pyramidal neurons examined.

\section{I. Characterization of responses to dynorphin}

Dynorphin had a predominantly inhibitory effect on the activity of hippocampal pyramidal cells. Application of the peptide for periods of 10 to $30 \mathrm{~s}$ produced a dose-dependent depression of both spontaneous and glutamate-evoked discharge in 24 of 37 and 27 of 44 pyramidal neurons tested in $\mathrm{CA}_{1}$ and $\mathrm{CA}_{3}$, respectively (table 1). Only four $\mathrm{CA}_{1}$ pyramidal cells and six $\mathrm{CA}_{3}$ cells displayed excitatory responses to dynorphin (table 1 ). Four additional pyramidal cells in each of the cellular fields responded in a biphasic manner to dynorphin application (table 1). In these latter cases, both electrophoretic $(n=5)$ and pneumatic pressure ejections $(n=3)$ of the peptide resulted in an initial brief excitation of several seconds duration followed by a prolonged period of spike suppression.

Fig. 1 illustrates the typical pattern of inhibi- tory effects of dynorphin that was encountered in a majority of the $\mathrm{CA}_{1}$ and $\mathrm{CA}_{3}$ pyramidal neurons tested. As shown in this $\mathrm{CA}_{1}$ cell, application of dynorphin by electrophoretic or pressure ejection produced reversible depressions in spike discharge which graded in magnitude and duration with the drug application parameters. Such depressant effects, observed in both $\mathrm{CA}_{1}$ and $\mathrm{CA}_{3}$, were typically rapid in onset, showed little evidence of tachyphylaxis and were produced equally well by electrophoretic or pressure ejection of the peptide. In most cases, recovery from the inhibitory effects of dynorphin on cell firing occurred gradually, beginning within a few seconds following cessation of peptide application. At the higher range of application doses, however, neuronal activity remained depressed for a number of seconds (20-100 s) after termination of peptide ejection, and recovery was often associated with rebound increases in baseline firing (fig. $1 \mathrm{~A}_{1}$ ). It should be noted that decreases in spike amplitude were observed in a small number of the cells $\left(\mathrm{CA}_{1} \mathrm{n}=4\right.$; $\mathrm{CA}_{3} \mathrm{n}=5$ ) which showed depressant responses to dynorphin. The changes in spike morphology ob-
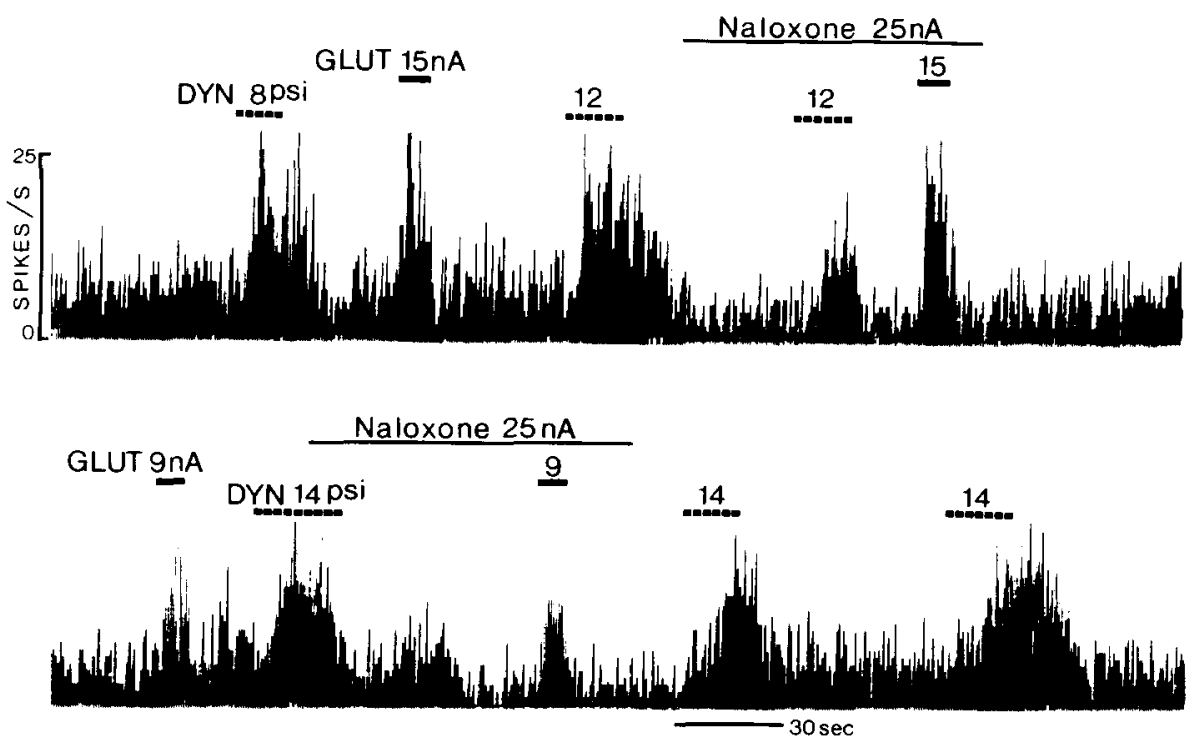

Fig. 2. Continuous ratemeter record shows excitations of a single $\mathrm{CA}_{3}$ pyramidal cell produced by glutamate (GLUT) iontophoresis and by pressure ejection of dynorphin (DYN). Excitatory responses produced by DYN application (dashed lines) were characterized by slow onset and prolonged duration, whereas increases in firing produced by iontophoresis of glutamate (thick bars) showed a rapid onset and termination corresponding to the period of amino acid application. Note that the excitatory effects of DYN could be blocked (upper record) or reversed (lower record) by iontophoresis of naloxone $25 \mathrm{nA}$ (thin lines) at a dose level which had no effect on glutamate-evoked increases in firing. 
served in these cases were, nevertheless, associated with clear reductions in neuronal discharge frequency (fig. $1 \mathrm{~A}_{2}$ ). In comparison, in those cells which showed biphasic responses to dynorphin, the inhibitory phase appeared to be due more to a decrease in action potential amplitude than to a decrease in the rate of neuronal firing per se.

Excitatory responses to dynorphin, which were observed in 10 of the 81 pyramidal neurons examined, appeared similar to those reported for other opioid peptides (Nicoll et al., 1977; Dunwiddie et al., 1980; French and Siggins, 1980; Henriksen et al., 1982). These excitatory effects were relatively slow in onset (fig. 2), beginning from 5 to $20 \mathrm{~s}$ after the initiation of either electrophoretic or pressure ejection of the peptide. The elevations in firing evoked by dynorphin were notably robust in nature, and such effects typically extended 10 or more seconds beyond the period of peptide application (fig. 2). In five of the ten cases, application of dynorphin also recruited firing of previously quiescent neighboring units, resulting in the concomitant appearance of multi-unit activity in the oscilloscope traces. No tachyphylaxis was observed to the excitatory action of dynorphin in any of the neurons, even under conditions when the peptide was applied repeatedly to the same cell for periods approaching $1 \mathrm{~h}$. Antagonism of excitatory responses to dynorphin was achieved with iontophoresis of naloxone in three of four $\mathrm{CA}_{1}$ and four of five $\mathrm{CA}_{3}$ pyramidal cells tested (fig. 2). This antagonism was unlikely to reflect a local anesthetic action of the opiate antagonist, since excitatory responses were reduced with doses of naloxone that had little effect on excitations evoked by glutamate (fig. 2 ).

\subsection{Nature of dynorphin's inhibitory action}

Previous studies have demonstrated predominantly facilitating effects of opiates and opioid peptides on hippocampal pyramidal cell activity, mediated presumably through a disinhibitory mechanism (Zieglgänsberger et al., 1979; Dunwiddie et al., 1980; Nicoll et al., 1980; Siggins and Zieglgänsberger, 1981). Although inhibitory responses to these substances have also been observed in some hippocampal neurons, such de- pressant effects were generally considered to be non-specific in nature or to otherwise reflect actions of the opioids on subpopulations of opiate receptors and/or hippocampal cells distinct from those mediating excitatory events (Nicoll et al., 1977; Fry et al., 1979; French and Siggins, 1980). Bearing this in mind, several types of experiments were conducted to clarify the events underlying the inhibitory effects of dynorphin on pyramidal cell discharge.

To determine whether the inhibitory responses to dynorphin involved the activation of opiate receptors, the specific opiate antagonist naloxone was applied prior to and concurrent with application of the peptide in tests on 14 pyramidal cells. Iontophoresis of naloxone ( 20 to $50 \mathrm{nA}, 2$ to 5 $\mathrm{min}$ ) failed in all cases either to prevent (eight of eight cells) or reverse (nine of nine cells) the inhibitory effects of dynorphin in $\mathrm{CA}_{1}$ and $\mathrm{CA}_{3}$ (fig. $1 A_{1}$ ). In fact, depressant responses to the pepticle were increased in five neurons during administration of the opiate antagonist. In four of these same cells, iontophoretic administration of naloxone alone depressed neuronal activity directly when ejected at current levels in excess of 30 $\mathrm{nA}$ (fig. $1 \mathrm{~A}_{1}$ ). This depression appeared to be due in large part to a local anesthetic action of naloxone and was likely to account for the apparent increase in inhibitory potency of dynorphin observed in the presence of the antagonist.

\subsection{Effects of structurally related opioids}

The involvement of opiate receptors in mediating the inhibitory effects of dynorphin was further assessed by characterizing the actions of other dynorphin peptides and of ethylketocyclazocine, a $\kappa$-receptor agonist, on hippocampal pyramidal cell activity. Des-Tyr-dynorphin, an opiate inactive fragment of dynorphin which has virtually no opiate binding potential (De Wied et al., 1978; Walker et al., 1982a), was tested on 19 neurons and found to have effects similar to that of the parent peptide (table 1). Pneumatic application of des-Tyr-dynorphin for periods of 10 to $20 \mathrm{~s}$ produced depressions of both spontaneous and glutamate-evoked firing in four of eight neurons tested in each of the cellular fields (fig. 3). A 

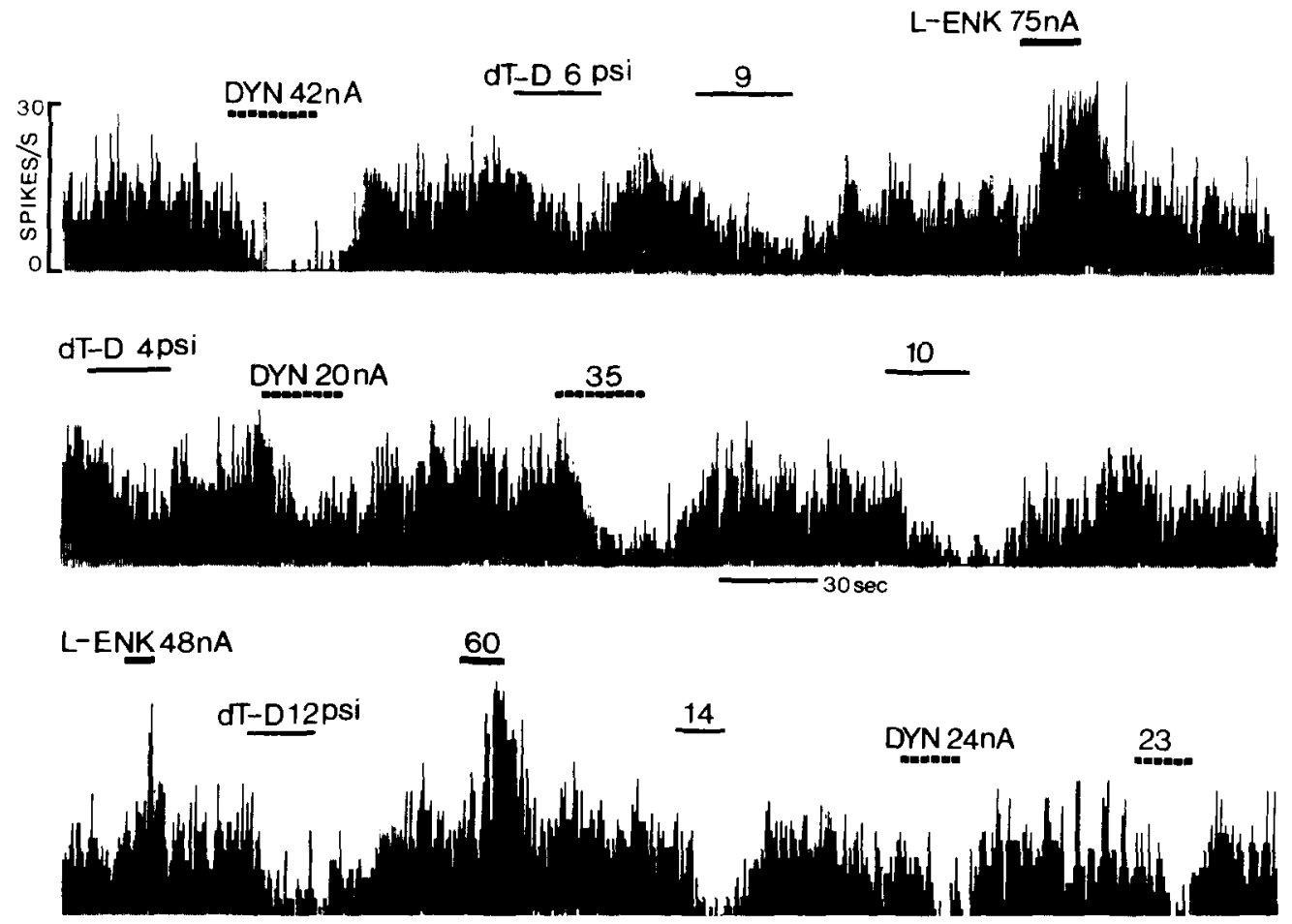

Fig. 3. Comparison of the effects of dynorphin (DYN), des-Tyr-dynorphin (dT-D) and [Leu ${ }^{5}$ enkephalin (L-ENK) on the activity of a single $\mathrm{CA}_{3}$ pyramidal neuron. Continuous ratemeter record illustrates dose-dependent inhibition of pyramidal cell spontaneous firing produced both by electrophoretic application of DYN (dashed bar) and by pressure ejection of its opiate inactive fragment dT-D (thin bar). Note that the inhibition produced by the two peptides displayed a similar onset and duration of effect. In comparison. iontophoretic application of L-ENK (thick bar) to the same neuron produced elevations in firing of slow onset and prolonged duration.

similar inhibitory action was observed in three additional $\mathrm{CA}_{3}$ neurons during electrophoretic application of the peptide. In contrast, electrophoretic $(n=3)$ or pressure ejection $(n=16)$ of des-Tyr-dynorphin elicited excitation of neuronal firing in only a single $\mathrm{CA}_{3}$ pyramidal cell (table 1). Seven cells displayed decreases in spike amplitude during pneumatic ejection of the peptide and were excluded from the analysis because of the possibility of pressure artifacts.

The actions of des-Tyr-dynorphin on pyramidal cell activity appeared to closely mimic those of dynorphin both in kind and quality of the effect. This similarity of action was demonstrated in tests on 14 neurons in which the effects of the two peptides were compared directly on the same neuron. Fig. 3 shows the results of a typical experiment on a single $\mathrm{CA}_{3}$ pyramidal cell. As shown in this neuron, application of either dynorphin or des-Tyr-dynorphin produced rapid and readily reversible depressions of spontaneous firing which graded in magnitude and duration with the level of electrophoretic current or pneumatic pressure used to eject a particular peptide. Iontophoresis of $\left[\right.$ Leu $^{5}$ ]enkephalin, in comparison, produced an elevation in cell discharge which was characterized by a slow onset and prolonged duration. Overall, eight of the 14 cells (four each in $\mathrm{CA}_{1}$ and $\mathrm{CA}_{3}$ ) were inhibited by administration of dynorphin, and in seven of these des-Tyr-dynorphin had similar depressant effects (table 2). Two additional cells in $\mathrm{CA}_{3}$ responded to dynorphin with excitation and in one of these cells des-Tyr-dynorphin elicited an identical response (table 2).

The actions in hippocampus of dynorphin-(1-8), an amino-terminal fragment which appears to be 


\section{TABLE 2}

Direct comparisons of the effects of dynorphin and related peptide fragments on pyramidal cell discharge. Values in tables indicate the number of cells responding in the same manner to dynorphin and a particular fragment peptide. Comparisons with des-Tyr-dynorphin were made in $6 \mathrm{CA}_{1}$ and $8 \mathrm{CA}_{3}$ cells; in $8 \mathrm{CA}_{3}$ cells with dynorphin-(1-8); and $6 \mathrm{CA}_{1}$ and $5 \mathrm{CA}_{3}$ cells with $\left[\right.$ Leu $\left.^{5}\right]$ enkephalin.

\begin{tabular}{llll}
\hline & \multicolumn{2}{l}{ Effects of dynorphin (No. of cells) } \\
\cline { 2 - 4 } & Inhibition & Excitation & No effect \\
\hline $\begin{array}{l}\text { Effects of peptide fragments } \\
\text { des-Tyr-Dynorphin } \\
\text { Inhibition }\end{array}$ & 7 & - & - \\
$\quad$ Excitation & - & 1 & - \\
$\quad$ No effect & 1 & 1 & 4 \\
Dynorphin-(1-8) & & & \\
Inhibition & 2 & - & - \\
$\quad$ Excitation & 2 & 1 & - \\
$\quad$ No effect & 2 & - & 1 \\
[Leu ${ }^{5}$ ]enkephalin & & & - \\
Inhibition & - & - & 2 \\
Excitation & 7 & - & \\
No effect & 1 & - & \\
\hline
\end{tabular}

the predominant dynorphin-like peptide in brain (Weber et al., 1982) were examined in seven $C_{1}$ and twelve $\mathrm{CA}_{3}$ pyramidal cells. Application of dynorphin-(1-8) had a predominantly excitatory effect in $\mathrm{CA}_{3}$, increasing the discharge rate of five neurons, while depressing activity in three cells (table 1). Three pyramidal cells in $\mathrm{CA}_{1}$ also responded to dynorphin-(1-8) in an excitatory manner (table 1). These excitatory effects were observed with both pressure (three cells) and electrophoretic ejection (five cells) of the peptide and were characteristically of slow onset and prolonged duration (fig. 4A). In three of four cells tested, excitatory responses to dynorphin-(1-8) were blocked by administration of naloxone at iontophoretic doses which caused little or no depression in spontaneous firing (fig. 4A). The inhibitory effects of dynorphin-(1-8) which were produced in three cells by pressure ejection of the octapeptide were not antagonized by naloxone (fig. 4B). The remaining eight cells in which dynorphin-(1-8) was tested showed no response to either electrophoretic or pressure application of the octapeptide (table 1).
Differences in the effects of dynorphin and dynorphin-(1-8) on hippocampal unit activity were assessed directly by comparing the actions of the two peptides on the same cell. Testing of both peptides was done on eight $\mathrm{CA}_{3}$ neurons with the method of their delivery being partitioned equally between pressure and electrophoretic application. Dynorphin showed a marked inhibitory potency. depressing spontaneous firing in six of the neurons (table 2). Two of these units were also inhibited by dynorphin-(1-8); however administration of the octapeptide caused marked elevations in firing in two other cells from this same population. Both peptides produced an elevation in firing in another neuron. Nonetheless, the response of this cell to dynorphin appeared atypical in that an initial excitatory effect of the peptide was converted to a depressant action upon repeated dynorphin administration (fig. 4A). Dynorphin-(1-8) had no effect on three of the eight neurons tested, suggesting a lower potency relative to dynorphin, similar to that observed in cumulative trials involving different populations of hippocampal pyramidal cells (table 1).

Shortening of the dynorphin molecule at its carboxy terminus has been shown both in receptor binding studies and in smooth muscle bioassays to result in a progressive decrease in the potency and $\kappa$-receptor selectivity of the respective fragment peptide (Chavkin and Goldstein, 1981; Corbett et al., 1982; James et al., 1984). To evaluate the possibility that the observed differences in actions of dynorphin and dynorphin-(1-8) might reflect such a difference in their $\kappa$ selectivity, the effects of ethylketocyclazocine on pyramidal cell activity were compared with those of the dynorphin peptides. In comparison with dynorphin's predominant inhibitory action, ethylketocyclazocine produced a mixed pattern of excitatory and inhibitory effects. Three of the nine and ten cells examined in $\mathrm{CA}_{1}$ and $\mathrm{CA}_{3}$, respectively, were inhibited by application of ethylketocyclazocine, while two cells in each of the cellular fields responded to the $\kappa$ agonist with an elevation in firing (table 1). In addition, five neurons showed biphasic responses to ethylketocyclazocine which consisted of an initial brief inhibition followed by a more prolonged excitatory phase. 
In six cases, the effects of ethylketocyclazocine and dynorphin-(1-8) were compared directly on the same cell. Both agents produced a dose-depen- dent inhibition of firing in two $\mathrm{CA}_{3}$ neurons. These inhibitory effects appeared similar in nature except for a more rapid onset observed with the

A
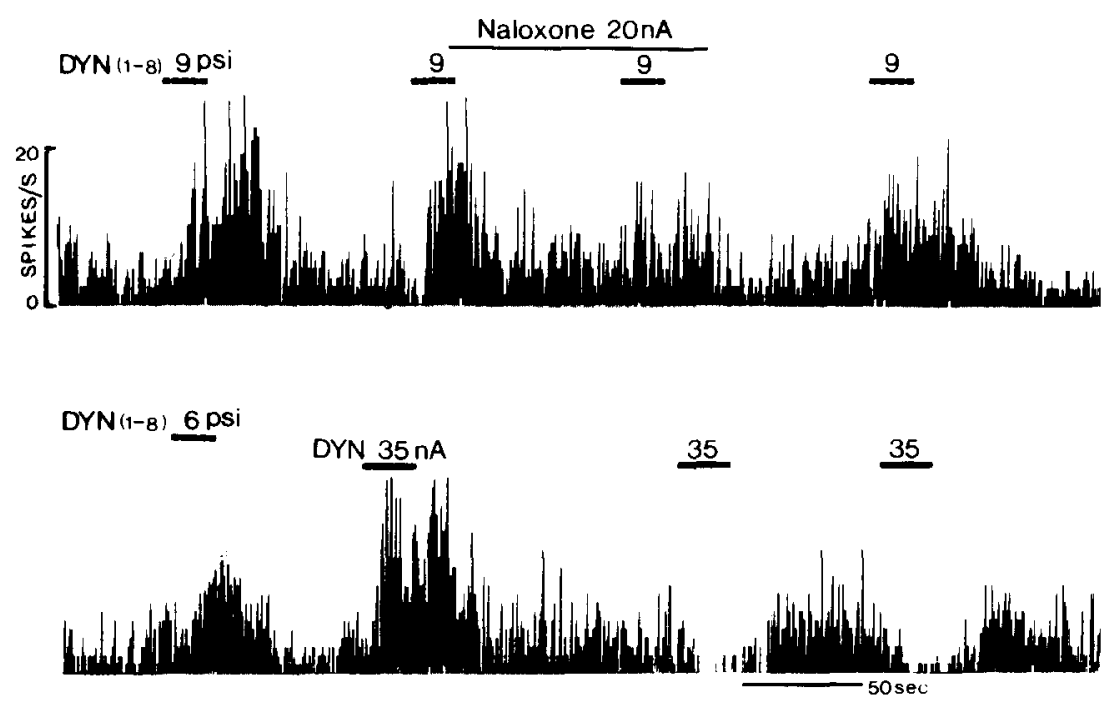

B
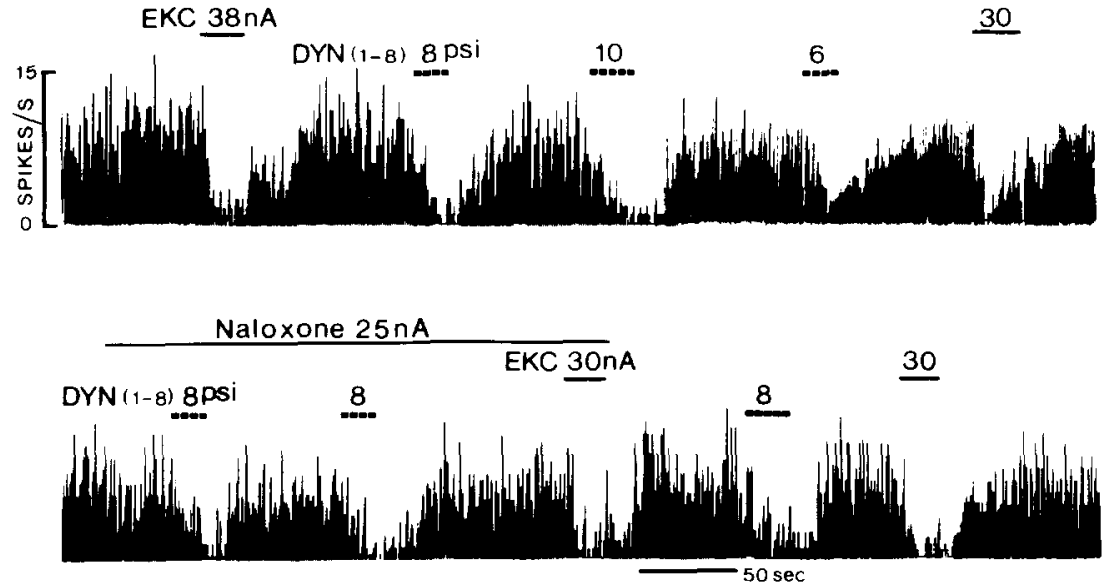

Fig. 4. (A) Continuous ratemeter record compares the effects of dynorphin-(1-8) $\left(\mathrm{DYN}_{(1-8)}\right)$ with that of dynorphin (DYN) on the activity of a $\mathrm{CA}_{3}$ pyramidal cell. Application of $\mathrm{DYN}_{(1-8)}$ (dashed lines) by pressure ejection produced a dose-dependent elevation in the spontaneous cell firing. This facilitating effect of $D Y N_{(1-8)}$ could be reversed or blocked by iontophoresis of naloxone $20 \mathrm{nA}$ (thin line). Electrophoretic application of DYN (thick bars) onto the same neuron had a biphasic effect, producing an initial excitatory response which converted to inhibition upon subsequent applications of the peptide. (B) Ratemeter records show inhibition of firing of another $\mathrm{CA}_{3}$ pyramidal cell produced by administration of ethylketocyclazocine (EKC) and dynorphin-(1-8) (DYN $(1-8)$ ). Pneumatic application of $\mathrm{DYN}_{(1-8)}$ (dashed lines) produced a gradual depression in neuronal firing which graded in magnitude with the level of ejection pressure. Electrophoretic administration of EKC (thin bars) produced inhibitions of cell firing having a much more rapid onset than those produced by $\mathrm{DYN}_{(1-8)}$. Iontophoresis of naloxone $25 \mathrm{nA}$ (thin line) failed to block the inhibitory effects of either compound. 
alkaloid (fig. 4B). Iontophoresis of naloxone failed to block the depressant actions of ethylketocyclazocine or dynorphin-(1-8) in either cell (fig. 4B). Application of dynorphin-(1-8) or ethylketocyclazocine produced marked increases in spontaneous firing in another $\mathrm{CA}_{3}$ neuron and in one $\mathrm{CA}_{1}$ pyramidal cell. In addition, one cell in each cellular field failed to respond to dynorphin-(1-8) application, but showed biphasic responses to ethylketocyclazocine.

In additional experiments, the effects of the dynorphin peptides on hippocampal unit activity were compared directly with the actions of $\left[\mathrm{Leu}^{5}\right]$ enkephalin on the same population of cells. The actions of dynorphin were examined together with those of $\left[\mathrm{Leu}^{5}\right]$ enkephalin in six $\mathrm{CA}_{1}$ and five $\mathrm{CA}_{3}$ pyramidal neurons. Four neurons in each of the cellular fields were inhibited by pressure $(n=4)$ or electrophoretic application $(n=4)$ of dynorphin (table 2). In seven of these cells, electrophoretic administration of $\left[\mathrm{Leu}^{5}\right]$ enkephalin produced elevations in firing (fig. 3 and table 2). [Leu $\left.{ }^{5}\right]$ enkephalin produced similar excitatory effects in two of three additional neurons which did not respond to the application of dynorphin (table 2). Whereas naloxone antagonized the excitatory effects of $\left[\mathrm{Leu}^{5}\right]$ enkephalin in three of four cells tested, the depressant responses of these neurons to dynorphin were not blocked by application of the antagonist.

Direct comparison were also made between the effects of dynorphin-(1-8) and [ $\left.\mathrm{Leu}^{5}\right]$ enkephalin in three $\mathrm{CA}_{3}$ pyramidal cells. Administration of $\left[\mathrm{Leu}^{5}\right]$ enkephalin resulted in increased firing in all three neurons. Similar facilitating effects were produced in two of the cells during electrophoretic as well as pressure ejection of dynorphin-(1-8). The excitatory effects of dynorphin-(1-8) and [ Leu $\left.^{5}\right]$ enkephalin in both cells were antagonized by iontophoresis of naloxone. Pressure application of dynorphin-(1-8) had no effect on the firing of the third cell tested.

\subsection{Cellular mediation of dynorphin's inhibitory ac- tion}

A final series of experiments was performed to gain insight into the cellular mechanism(s) un- derlying dynorphin's inhibitory effect on pyramidal cell activity. The possibility that the inhibitions in cell firing produced by application of the peptide might reflect a direct action of dynorphin on pyramidal cells was tested initially by examining neuronal responses to dynorphin under conditions in which ongoing synaptic activity was reduced or eliminated by concurrent iontophoretic administration of magnesium (Nicoll, 1971). In these experiments, presynaptic activity was judged to be effectively abolished during magnesium administration by the demonstrated blockade of orthodromic activation of $\mathrm{CA}_{1}$ and $\mathrm{CA}_{3}$ pyramidal cells, respectively, following electrical stimulation of the Schaffer collateral and mossy fiber afferents. As shown by the results from one such experiment (fig. 1B), electrophoretic applications of dynorphin consistently produced inhibitions of pyramidal cell firing throughout the period of magnesium iontophoresis. Little or no decrement was observed in the inhibitory effect of dynorphin either during or after magnesium administration in any of the eight pyramidal cells tested. In these experiments, administration of magnesium alone ( 5 to $30 \mathrm{nA}, 2$ to $7 \mathrm{~min}$ ) produced direct slowing of discharge in six of the cells and elevations in firing in two neurons.

Much evidence suggests that the activity of hippocampal pyramidal cells is under tonic inhibitory control from local $\gamma$-aminobutyric acid (GABA)-containing inhibitory interneurons (Andersen, 1975; Ribak et al., 1978). Because these interneurons have been implicated as a primary target of opioid action in the hippocampus (Zieglgänsberger et al., 1979; Nicoll et al., 1980; Siggins and Zieglgänsberger, 1981), experiments were next carried out with bicuculline to assess the possible involvement of GABA in the mediation of dynorphin's inhibitory effects. Iontophoresis of bicuculline ( 20 to $65 \mathrm{nA}, 20$ to $90 \mathrm{~s}$ ) accelerated the firing of all six pyramidal cells tested (data not shown) as would be expected assuming tonic release of endogenous GABA. In four cells, inhibitory responses to dynorphin remained at or near control levels during administration of the GABA antagonist. In two cells, a partial antagonism of dynorphin responses was achieved by application of bicuculline several minutes prior to ejection of 
the peptide. This apparent antagonism appeared mainly due to a nonspecific speeding action of bicuculline, however, since depressions in firing produced by cationic current pulses were similarly reduced by the drug.

\section{Discussion}

The present results confirm our previously reported finding (Walker et al., 1982a) that dynorphin has a predominantly depressant effect on hippocampal pyramidal cell activity. Fifty-one of the $69 \mathrm{CA}_{1}$ and $\mathrm{CA}_{3}$ pyramidal cells which responded to dynorphin showed depression in their firing during electrophoretic or pressure ejection of the peptide. These inhibitory responses graded in magnitude and duration directly in relation to the drug ejection parameters and generally occurred independent of any reduction in the amplitude of the extracellularly recorded action potentials. It seems unlikely, therefore, that the depressions in spike firing produced here by dynorphin can be attributed either to depolarization blockade or to a non-specific effect of the peptide on membrane excitability. The possibility that these depressant responses may have come from testing of the peptide on neurons other than pyramidal cells (see Zieglgänsberger et al., 1979) can also be ruled out, since many of the same neurons which were inhibited by dynorphin exhibited excitatory responses to [ $\left.\mathrm{Leu}^{5}\right]$ enkephalin in a manner similar to that reported by other investigators. Depressions in pyramidal cell firing were also produced, although to a much lesser extent, by application of dynorphin-(1-8), an amino-terminal fragment of dynorphin which appears to be the major dynorphin-like peptide released in brain (Weber et al., 1982). Overall, we interpret these findings to suggest that an important component of the action of the dynorphin peptides in hippocampus may be to modulate the level of pyramidal cell activity.

Dynorphin produced elevations in firing rate in a small fraction of the pyramidal cells tested. These excitatory effects of dynorphin appeared similar in character to those found with enkephalin peptides both here and in previous reports (Nicoll et al., 1977; Zieglgänsberger et al., 1979;
Dunwiddie et al., 1980; Henriksen et al., 1982). This spike facilitating action of dynorphin further resembled that of $\left[\mathrm{Leu}^{5}\right]$ enkephalin in terms of its sensitivity to antagonism by naloxone, suggesting that such effects may be mediated by classical opioid receptors.

Henriksen and co-workers (1983) reported a similar excitatory action of dynorphin on hippocampal pyramidal cell discharge in rat. In contrast to the present findings, however, these investigators found that dynorphin had a predominantly facilitating effect on the firing of both $\mathrm{CA}_{1}$ and $\mathrm{CA}_{3}$ pyramidal cells. This discrepancy in experimental findings can possibly be attributed to a difference in the sampling methods that were used in the studies, and thus in the overall make-up of the populations of pyramidal cells on which the peptide was tested. Whereas all cells sampled in the present study either displayed significant levels of spontaneous activity or were driven to fire with glutamate, Henriksen and his coworkers confined their analysis of dynorphin action primarily to slowly firing neurons and normally quiescent cells (Henriksen and Chouvet, personal communication). Conceivably, the effects of dynorphin may differ in these two populations of pyramidal neurons. In this regard, Hill and coworkers (1977) have shown that the direction of the response of hippocampal neurons to enkephalin peptides can vary with the activity level of the cell, shifting from excitation to depression when firing is increased by glutamate. The speculation raised here is that the probability of recording excitation or depression to dynorphin application may be related to the excitability state of a particular neuron, which may in turn be governed by the particular types of synaptic input the cell receives. In fact, our preliminary intracellular findings obtained in the hippocampal slice (Pacheco et al., 1983) indicate that dynorphin has direct membrane actions on pyramidal neurons, and that these effects are voltage-dependent, changing in magnitude and direction in relation to the membrane potential of the cell. The results of the experiments with magnesium and bicuculline also provide evidence consistent with a postsynaptic mediation of dynorphin's inhibitory action on pyramidal cell firing. 
Whereas the excitatory responses to dynorphın appear to involve the activation of classical opiate receptors, the nature of the events underlying the inhibitory effects of the peptide can not be so readily explained. The finding that only the facilitating effects of dynorphin were effectively antagonized by naloxone suggests as one possibility that different mechanisms may account for the excitatory and inhibitory actions observed here. On the other hand, the inhibitory actions of the peptide could reflect $\kappa$ opioid effects, which often are naloxone resistant (Gilbert and Martin, 1976; Hutchinson et al., 1975). This possibility is supported by the finding that the $\kappa$-receptor agonist ethylketocyclazocine produced depressant effects similar to those of dynorphin in a number of cells. An inhibitory effect of ethylketocyclazocine on pyramidal cell firing was also reported by Henriksen and coworkers (1982). In comparing the neuronal actions of opioids and opiate alkaloids having different receptor selectivities, these workers (Henriksen et al., 1983) noted further that a shift in agonist selectivity from $\mu$ - or $\delta$ - to $\kappa$-directed activity was usually associated with an increase in the proportion of inhibitory over excitatory effects produced. The high incidence of excitatory effects found here with dynorphin-(1-8) might then be attributed to its greater cross reaction with $\mu$-receptors (Corbett et al., 1982; James et al., 1984), whereas, dynorphin in comparison appears to be predominantly $\kappa$-directed (Chavkin et al., 1982; Corbett et al., 1982; James et al., 1984). Nevertheless, the failure of naloxone to block the inhibitory effects of dynorphin presents considerable difficulty, since reversibility of effects by the antagonist remains the sine-qua-non of opiate activity. Despite a marked resistance shown to naloxone antagonism, virtually all $\kappa$ opioid effects observed in isolated smooth muscle preparations or in brain homogenate binding assays can ultimately be completely reversed by naloxone (Hutchinson et al., 1975; Lord et al., 1977). Yet, no instance of naloxone reversal of dynorphin's depressant effect on pyramidal cell discharge was found here or in previously published reports (Henriksen et al., 1982; Walker et al., 1982a).

An alternative possibility to consider, based on the outcome of tests with naloxone, is that the inhibitory actions of dynorphin may be non-opiate in nature. Adding support to this suggestion was the finding that des-Tyr-dynorphin, a peptide fragment with virtually no opiate-binding potential (De Wied et al., 1978; Walker et al., 1982a), produced effects on pyramidal cell activity that were virtually indistinguishable from those of $\mathrm{dy}$ norphin. It should be noted that in a variety of other test systems des-Tyr-dynorphin produced effects which closely mimicked those of the full dynorphin sequence as well. These include effects in rodents on the electroencephalogram, motor behavior and grooming (Aloyo et al., 1982; Walker et al., 1982a), the inhibition of morphine-induced analgesia (Walker et al., 1982b), and a syndrome of spinal paralysis (Przewlocki et al., 1983), to name but a few. Thus, there seems sufficient evidence for postulating the existence of a second biologically active site within the dynorphin molecule which is non-opiate, but capable of potent physiological effects. Presumably, the profile of pharmacological effects produced by des-Tyr-dynorphin might then reflect such a non-opiate component of dynorphin's action with unknown mechanism. However, the recent observation that desTyr-dynorphin inhibits the amino-terminal cleavage of $\left[{ }^{3} \mathrm{H}\right]$ dynorphin in brain (E.A. Young, personal communication) raises the possibility that this substance may act in part by inhibiting the breakdown of endogenously released dynorphin. Experiments are presently underway to distinguish among these alternatives.

In the event that dynorphin is found to have several active sites, it would not make the peptide unique. Indeed, such is the case for $\gamma$-endorphin, whose des-tyrosine counterpart is non-opiate but very potent biologically (De Wied et al., 1978). Non-opiate binding sites for $\beta$-endorphin have been documented in the periphery (Schweigerer et al., 1983). Moreover, it has recently been reported that a centrally occurring carboxy-terminal cleavage of $\beta$-endorphin results in the secretion of a neurally active dipeptide (Smyth et al., 1983) and a fragment of $\beta$-endorphin ( $\beta$-endorphin-(1-27)) having considerably reduced activity at opiate receptors (see Akil and Watson, 1983). In view of these findings, and given that opioid peptides (namely, dynorphin A, $\alpha$-neo-endorphin and 
rimorphin) account for less than 20 percent of the total pro-dynorphin precursor, it might be fruitful to consider the possibility that biologically significant non-opiate actions, in addition to opiate-related effects, may occur upon the liberation of pro-dynorphin peptides.

A final issue concerns the extent to which the effects found here with the application of dynorphin peptides might reflect a normal physiological action of the dynorphin input to hippocampus. Radioimmunoassay and immunocytochemical studies have revealed that dynorphin-like immunoreactive (IR) material is present in hippocampus in high concentrations within the dentate granule cell-mossy fiber pathway (Khachaturian et al., 1982; McGinty et al., 1983). Much of this dynorphin-IR appears to correspond to the amino-terminal octapeptide fragment, dynorphin(1-8) (Weber et al., 1982), although appreciable amounts of the heptadecapeptide form of $\mathrm{dy}$ norphin have also been detected and shown recently to be released (Chavkin et al., 1983). Classically, the mossy fibers have been thought to monosynaptically excite the $\mathrm{CA}_{3}-\mathrm{CA}_{4}$ pyramidal neurons, presumably through the release of a conventional amino acid neurotransmitter (Cotman, 1981). Yet, the finding in this study that dynorphin-(1-8) exerted potent facilitating effects on pyramidal cell activity suggests that a dynorphinlike peptide may figure prominently in mediating the action of this intrinsic hippocampal fiber system. A similar argument could be made for dynorphin, itself, since excitatory effects were also produced by the complete peptide sequence in some neurons. Nevertheless, it could be that dynorphin peptides coexist with an excitatory amino acid transmitter within the same mossy fiber terminals, and that the actions of the peptides are normally co-expressed with that of the classical neurotransmitter. Indeed, this suggestion is in keeping with recent immunohistochemical data which demonstrate such coexistence of neuropeptides and classical transmitters in a variety of different neurons (Lundberg and Hökfelt, 1983). In a number of these cases the peptides appear to modify the effects caused by the classical agent. Conceivably, the inhibitory responses observed here with dynorphin could reflect a similar peptide action, which may function normally to modulate the effectiveness of synaptic transmission at mossy fiber-pyramidal cell junctions. Insight into these questions requires that in future studies one consider the actions of dynorphin peptides within the context of a dynamic interplay with ongoing hippocampal synaptic circuitry.

\section{Acknowledgements}

The authors wish to thank Dr. Huda Akil for providing laboratory facilities during the initial stages of this work and Dr. David H. Coy for the generous gift of dynorphin and des-Tyr-dynorphin.

\section{References}

Akil, H. and S.J. Watson, 1983, Beta-endorphin and biosynthetically related peptides in the central nervous system, in: Handbook of Psycho-pharmacology, Vol. 16, eds. L. Iversen, S.D. Iversen and S.H. Snyder (Plenum, New York) p. 209.

Aloyo, V.J., B. Spruijt, H. Zwiers and W.H. Gispen, 1982 , Peptide-induced excessive grooming behavior: the role of opiate receptors, Neurosci. Abstr. 8, 371

Andersen, P., 1975, in: The Hippocampus, Vol. 1, eds. R.L. Isaacson and K.H. Pribram (Plenum, New York) p. 155.

Chavkin, C., C. Bakhit and F.E. Bloom, 1983, Evidence for dynorphin-A as a neurotransmitter in rat hippocampus, Life Sci. 33, Suppl. I, 13.

Chavkin, C. and A. Goldstein, 1981, Specific receptor for the opioid peptide dynorphin: structure-activity relationships, Proc. Natl. Acad. Sci. U.S.A. 78, 6543.

Chavkin, C., I.F. James and A. Goldstein, 1982, Dynorphin is a specific endogenous ligand of the $x$ opioid receptor, Science $215,413$.

Corbett, A.D., S.J. Paterson, A.T. McKnight, J. Magnan and H. Kosterlitz, 1982, Dynorphin ${ }_{1-8}$ and dynorphin 1-9 $_{\text {are }}$ ligands for the $\kappa$-subtype of opiate receptor, Nature 299, 79.

Cotman, C., 1981, Regulatory Mechanisms of Synaptic Transmission (Plenum, New York) p. 422.

De Wied, D., G.L. Kovács, B. Bohus, J.M. Van Ree and H.M. Greven, 1978, Neuroleptic activity of the neuropeptide B$\mathrm{LPH}_{62-77}$ (des-Tyr- $\gamma$-endorphin: DT $\gamma \mathrm{E}$ ), European J. Pharmacol. 49, 427.

Dingledine, R., 1981, Possible mechanisms of enkephalin action on hippocampal $\mathrm{CA}_{1}$ pyramidal neurons, J. Neurosci. $1,1022$.

Dunwiddie, T., A. Mueller, M. Palmer, J. Stewart and B. Hoffer, 1980, Electrophysiological interactions of enkephalins with neuronal circuitry in the rat hippocampus. I. Effects on pyramidal cell activity, Brain Res. 184, 311. 
Faden, A.I. and T.P. Jacobs, 1984, Dynorphin related peptides cause motor dysfunction in the rat through a non-opiate action, Br. J. Pharmacol. 81, 271.

French, E.D. and G.R. Siggins, 1980, An iontophoretic survey of opioid peptide actions in the rat limbic system: in search of opiate epileptogenic mechanisms, Reg. Peptides 1. 127.

Fry, J.P., W. Zieglgänsberger and A. Herz, 1979, Specific versus non-specific actions of opioids on hippocampal neurons in the rat brain, Brain Res. 163, 295.

Gilbert, P.E. and W.R. Martin, 1976, The effects of morphine and nalorphine-like drugs in the nondependent, morphinedependent and cyclazocine-dependent chronic spinal dog, J. Pharmacol. Exp. Ther. 198, 66.

Henriksen, S.J., G. Chouvet and F.E. Bloom, 1982, In vivo cellular responses to electrophoretically applied dynorphin in the rat hippocampus, Life Sci. 31, 1785.

Henriksen, S.J., G. Chouvet and F.E. Bloom, 1983, Differential responses of hippocampal neurons to endogenous opioid peptides and opiate alkaloids suggest multiple opiate receptors, Neurosci. Abstr. 13, 1130.

Herman, B.H., F. Leslie and A. Goldstein, 1980, Behavioral effects and in vivo degradation of intraventricularly administered dynorphin and D-Ala ${ }^{2}$-dynorphin-(1-11) in rats. Life Sci. 27, 883.

Hill, R.G., J.F. Mitchell and C.M. Pepper, 1977, The excitation and depression of hippocampal neurons by iontophoretically applied enkephalins, J. Physiol. 272, 50P.

Huidobro-Toro, J.P., K. Yoshimura, N.M. Lee, H.L. Loh and E.L. Way, 1981, Dynorphin interaction at the $\kappa$-opiate site, European J. Pharmacol. 72, 265.

Hutchinson, M., H.W. Kosterlitz, F.M. Leslie, A.A. Waterfield and Terenius, L., 1975, Assessment in the guinea-pig ileum and mouse vas deferens of benzomorphans which have strong antinociceptive activity but do not substitute for morphine in the dependent monkey, Br. J. Pharmacol. 55, 541.

James, I.F., W. Fischli and A. Goldstein, 1984, Opioid receptor selectivity of dynorphin gene products, J. Pharmacol. Exp. Ther. 228, 88,

Khachaturian, H., S.J. Watson, M.E. Lewis, D. Coy, A. Goldstein and H. Akil, 1982, Dynorphin immunocytochemistry in the rat central nervous system, Peptides 3, 941.

Lord, J.A.H., A.A. Waterfield, J. Hughes and H.W. Kosterlitz, 1977, Endogenous opioid peptides: multiple agonists and receptors, Nature 267, 495.

Lundberg, J.M. and T. Hökfelt, 1983, Coexistence of peptides and classical neurotransmitters, Trends Neurosci. 6, 325.

McGinty, J.F., S.J. Henriksen, A. Goldstein, L. Terenius and F.E. Bloom, 1983, Dynorphin is contained within hippocampal mossy fibers: immunohistochemical alterations after kainic acid administration and colchicine-induced neurotoxicity, Proc. Natl. Acad. Sci. U.S.A. 80, 589.

Nicoll, R.A., 1971, Pharmacological evidence for GABA as the transmitter in granule cell inhibition in the olfactory bulb, Brain Res. 35, 137
Nicoll, R.A., B.E. Alger and C.E. Jahr, 1980, Enkephalin blocks inhibitory pathways in the vertebrate CNS, Nature 287, 22.

Nicoll, R.A., G.R. Siggins, N. Ling, F.E. Bloom and R. Guillemin, 1977, Neuronal actions of endorphins and enkephalins among brain regions. A comparative microiontophoretic study. Proc. Natl. Acad. Sci. U.S.A. 74, 2584.

Pacheco, M.F., J.M. Walker and H.C. Moises, 1983, Direct membrane actions of dynorphin on pyramidal cells in rat hippocampal slices, Neurosci. Abstr. 13, 741.

Palmer, M.R., S.M. Wuerthele and B.J. Hoffer, 1980, Physical and physiological characteristics of micropressure ejection of drugs from multibarreled pipettes. Neuropharmacology $19,931$.

Przewlocki, R., G.T. Shearman and A. Herz, 1983, Mixed opioid/nonopioid effects of dynorphin and dynorphin related peptides after their intrathecal injection in rats. Neuropeptides 3, 233.

Ribak, E.C., J.E. Vaughn and K. Saito, Immunocytochemical localization of glutamic acid decarboxylase in neuronal somata following colchicine inhibition of axonal transport. Brain Res. 140, 315 .

Schweigerer, L., H.H. Teschemacher, S. Bhakdi and M. Lederle, 1983. Interaction of human $\beta$-endorphin with nonopiate binding sites on the terminal SC56-9 complex of human complement, J. Biol. Chem. 258, 12287.

Siggins, G.R. and W. Zieglgänsberger, 1981, Morphine and opioid peptides reduce inhibitory synaptic potentials in hippocampal pyramidal cells in vitro without alteration of membrane potential, Proc. Natl. Acad. Sci. U.S.A. 78, 5235.

Smyth, D.G., D.C. Parish, J.R. Normanton and J.H. Wolstencroft, 1983, The $C$-terminal dipeptide of $\beta$-endorphin: a neuropeptide with inhibitory activity, Life Sci. 33, 575.

Walker, J.M., R.J. Katz and H. Akil, 1981. Behavioral effects of dynorphin ${ }_{1-13}$ in the mouse and rat: Initial observations, Peptides 1, 341

Walker, J.M.. H.C. Moises, D.H. Coy, G. Baldrighi and H. Akil, 1982a, Non-opiate effects of dynorphin and desTyr-dynorphin, Science 218, 1136.

Walker, J.M., D. Tucker, B. Walker and H. Akil, 1982b, Des-tyrosine-dynorphin inhibits morphine analgesia, European J. Pharmacol 85, 121.

Weber, E., C.J. Evans and J.D. Barchas, 1982. Predominance of the amino-terminal octapeptide fragment of dynorphin in rat brain regions, Nature 299, 77.

Yoshimura, K., J.P. Huidobro-Toro, N.M. Lee, H.H. Loh and E.L. Way, 1982, $\kappa$ opioid properties of dynorphin and its peptide fragments on the guinea pig ileum, J. Pharmacol. Exp. Ther. 222, 71.

Young, E.A., J.M. Walker, R. Houghton and H. Akil, 1983, $\left[{ }^{3} \mathrm{H}\right]$ Dynorphin binds selectively in guinea pig brain. European J. Pharmacol. 91, 327.

Zieglgänsberger, W., E.D. French, G.R. Siggins and F.E. Bloom, 1979, Opioid peptides may excite hippocampal pyramidal neurons by inhibiting adjacent interneurons, Science 205 . 415 . 